\title{
Agrometeorological drought in the Romanian plain within the sector delimited by the valleys of the Olt and Buzău Rivers
}

\author{
Ovidiu Murărescu, George Murătoreanu* and Mădălina Frînculeasa
}

\begin{abstract}
Background: The last few decades have recorded a high frequency of the meteorological drought phenomenon. Southern and south-eastern Romania make no exception, with such phenomena often occurring from July to November 2011, which brought about an agrometerological drought that lasted from the third decade of July to early December, with a slight improvement in October. This situation led to a decrease in soil water reserves, mainly in the first $20 \mathrm{~cm}$, with a negative impact on agricultural crops and the following agricultural year as well.
\end{abstract}

Findings: The methodology was based on a correlative analysis between the decadal rainfall quantities and the existing soil water reserve, during the interval between June and November 2011, for eight weather stations.

Conclusion: The statistico-mathematical data analysis showed an intensification of the pedological drought phenomenon in September, with a slight improvement in October and an increase in November.

Keywords: Precipitation, Temperatures, Water climatic, Drought, Soil

\section{Introduction}

The increase of the meteorological drought phenomenon leads to the occurrence of the pedological drought and, hence, of aridity, combined with a high soil temperature and evapotranspiration. Such situations, according to statistical history, were recorded in 2000, 2001, 2007, 2011, 2012 and 2013.

The analysed geographical area includes the Romanian Plain, more exactly the sector between the left bank of the Olt river - in the west - as far as its confluence with the Danube; north-eastern boundary is located on the right bank of the Buzău river; the northern is conventionally located north of Slatina, Valea Mare, Potcoava, then the contact between the Cotmeanu Piedmont and the 5th terrace of the Argeş river as far as north of Pitești, stretching along the contact with the Outer Subcarpathian Curvature Hills; the southern boundary is located at the contact with the Danube valley, while the eastern overlaps the interference between the forest-steppe and the forest - the Argeş river meadow, from the confluence

\footnotetext{
* Correspondence: muratoreanug@yahoo.com

Department of Geography, Valahia University of Târgoviște, Târgoviște,
} Romania

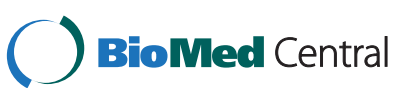

with the Dâmbovița river to its flow into the Danube, then Dâmbovița - Pasărea - Obârşia Mostiştei and Sărata boundary with the Bărăgan Plain [1] (Figure 1).

There have been concerns regarding the analysis of the phenomena of aridity occurrence ever since early 20th century (Lang - 1920 - the rain factor; De Martonne - 1926 the aridity index - etc.). In Romania, many climatological geographers have had similar preoccupations [2-19].

\section{Data and working methods}

The present study does not aim to calculate the climatic water deficit (CWD) and the De Martonne aridity index $\left(\mathrm{I}_{\mathrm{ar}}\right)$, as these parameters have already been identified, and correlations between them have also been made $[11,14,17]$, therefore the territorial map of the aridity index in Romania $-\mathrm{mm} /{ }^{\circ} \mathrm{C}$ has been drawn as well [2].

This approach aims rather to identify and characterise the agrometeorological phenomena of hydric risk by taking into consideration parameters and critical thresholds during the intervals which are specific to phenological processes and phases. Such analyses can be performed decadally, bimonthly, monthly, seasonally, annually or permanently with a view to adopting negative effect prevention and reduction measures [20]. In this regard, we have 


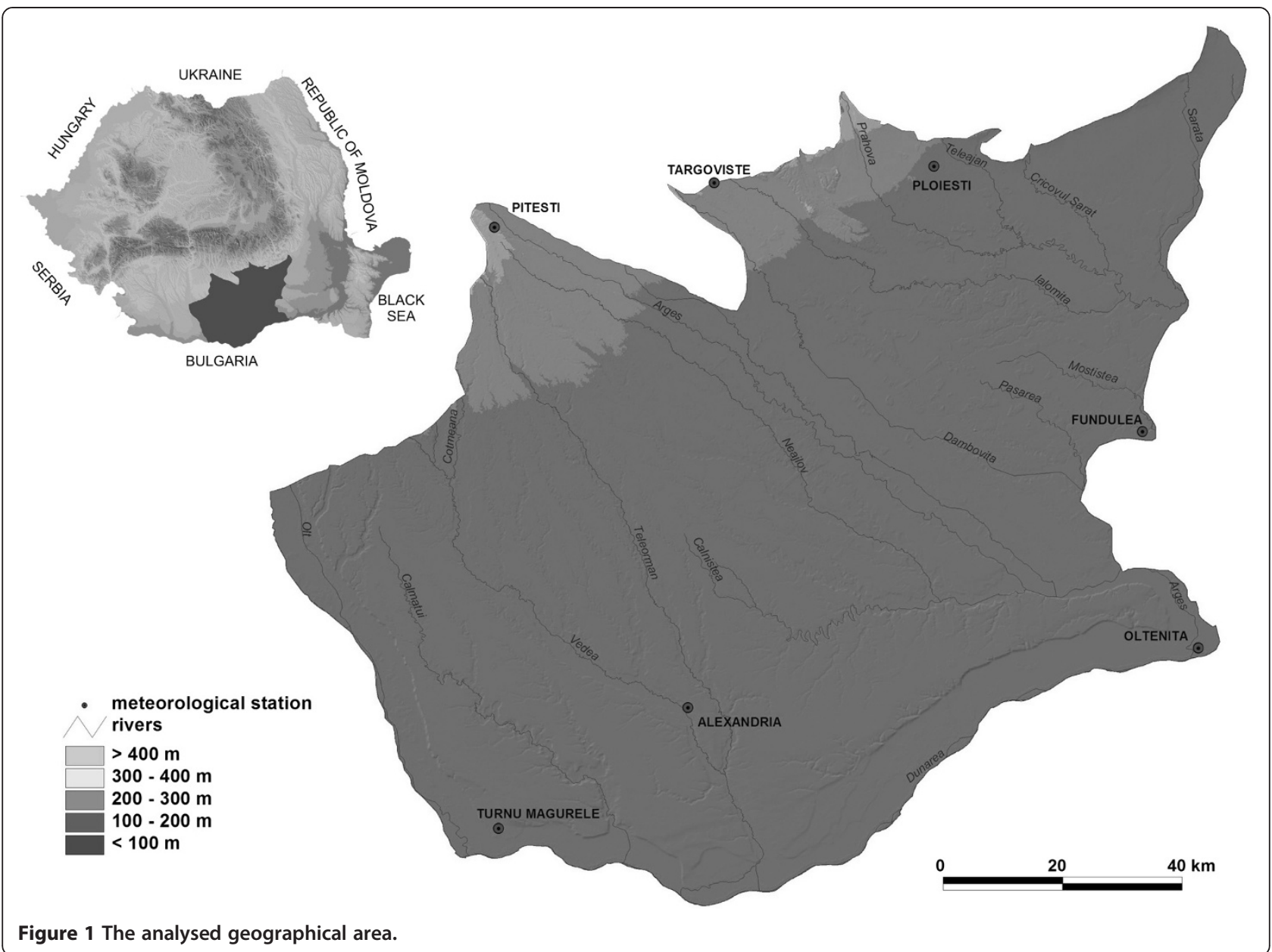

conducted a correlative analysis between the decadal rainfall quantities and the existing soil water reserve, during the interval between June and November 2011, for eight weather stations (Pitești, Ploiești, Târgovişte, Turnu Măgurele, Alexandria, Oltenția, Fundulea).

The soil moisture considered was determined from the surface to one-metre depth by $20-\mathrm{cm}$ sections. The available moisture is calculated based on the volumetric weight of the soil stratum considered $(\mathrm{Vw})$, existing moisture content (U) and the wilting point (WP), according to the following formula:

$$
\mathrm{AWC}=0.1 \times \mathrm{VW} \times(\mathrm{U} \%-\mathrm{WP}) \times \mathrm{h}
$$

where $\mathrm{AWC}=$ available moisture, and $\mathrm{h}=$ depth.

\section{Findings}

In the calendar year 2011, the annual mean temperature in Romania was $9.2^{\circ} \mathrm{C}, 0.3^{\circ} \mathrm{C}$ higher than the climatological normal, with positive deviations between $0.1^{\circ} \mathrm{C}$ (in March and May) and $2-6^{\circ} \mathrm{C}$ in September, but also with negative deviations in February, April, October and
November $\left(0.1^{\circ} \mathrm{C}\right.$ - April up to $2.7^{\circ} \mathrm{C}$ in November) from the climatological normals.

The country average annual rainfall was $500.4 \mathrm{~mm}$, $22 \%$ under the climatological normal, due to the deficits recorded in most months. The excess rainfall was in June-July, while the rest of the months were characterised by deficit, with negative deviations ranging between 1097\%. Months with deficit were March (40\%), August (53\%), September (72\%) and November (97\%). As a result, the year 2011 was characterised by low rainfall, with November the driest month, and by pedological drought installed differentially at regional level [21].

The statistico-mathematical data analysis of decadal rainfall quantities recorded at the eight agrometeorological stations located in the field region under study, correlated with the soil water reserve recorded in July-November 2011, showed an intensification of the pedological drought phenomenon in September, with a slight improvement in October and an increase in November.

The average available moisture (AWC) required for plant development, according to norms, is 400 at 20 -cm depth, 820 at $40 \mathrm{~cm}$ and 1500 at $80 \mathrm{~cm}$. 

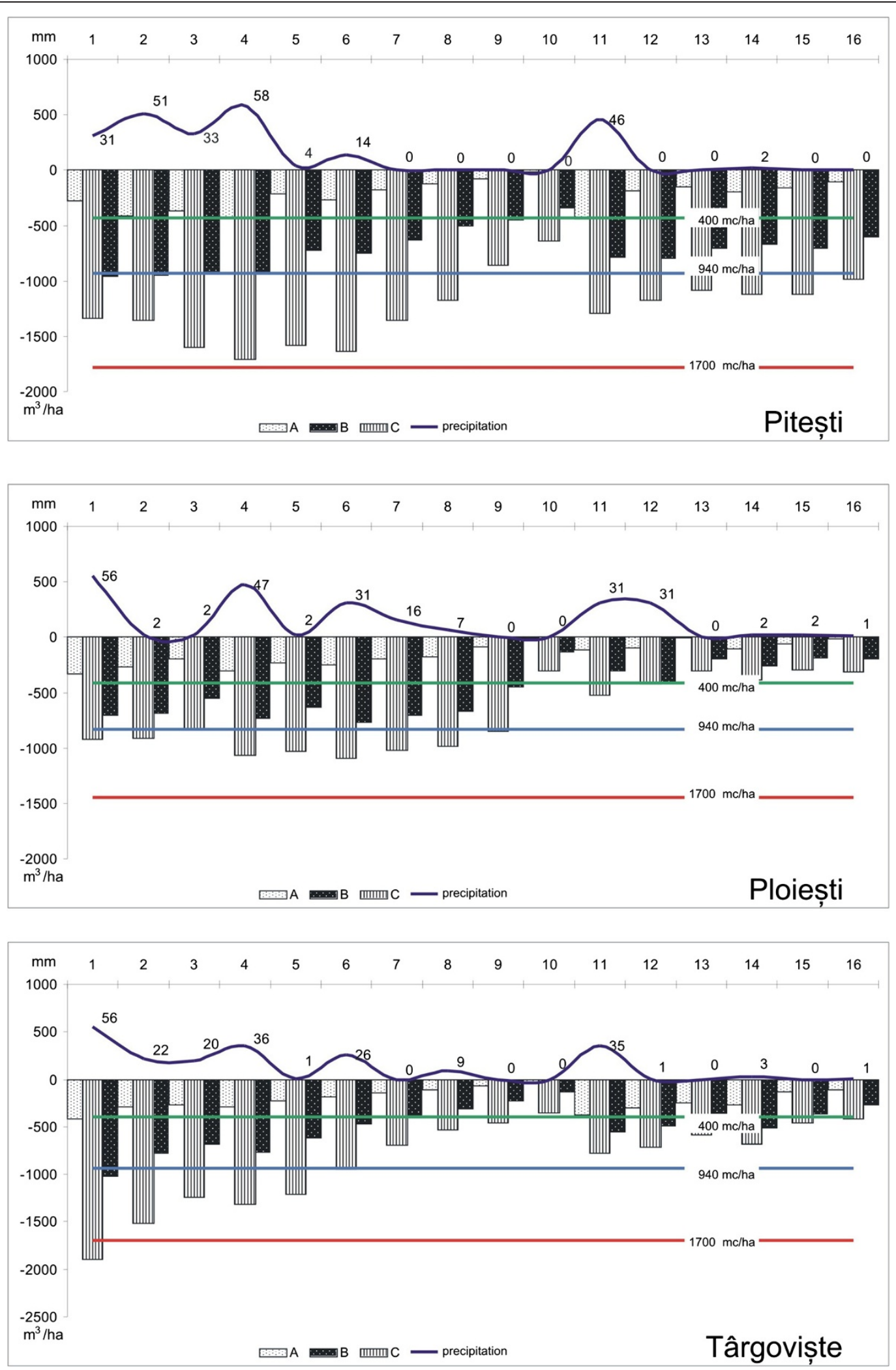

Figure 2 The average available moisture (AWC) and the soil moisture reserve for the agrometeorological station situated in the north of the plain (data source: National Meteorology Administration). 


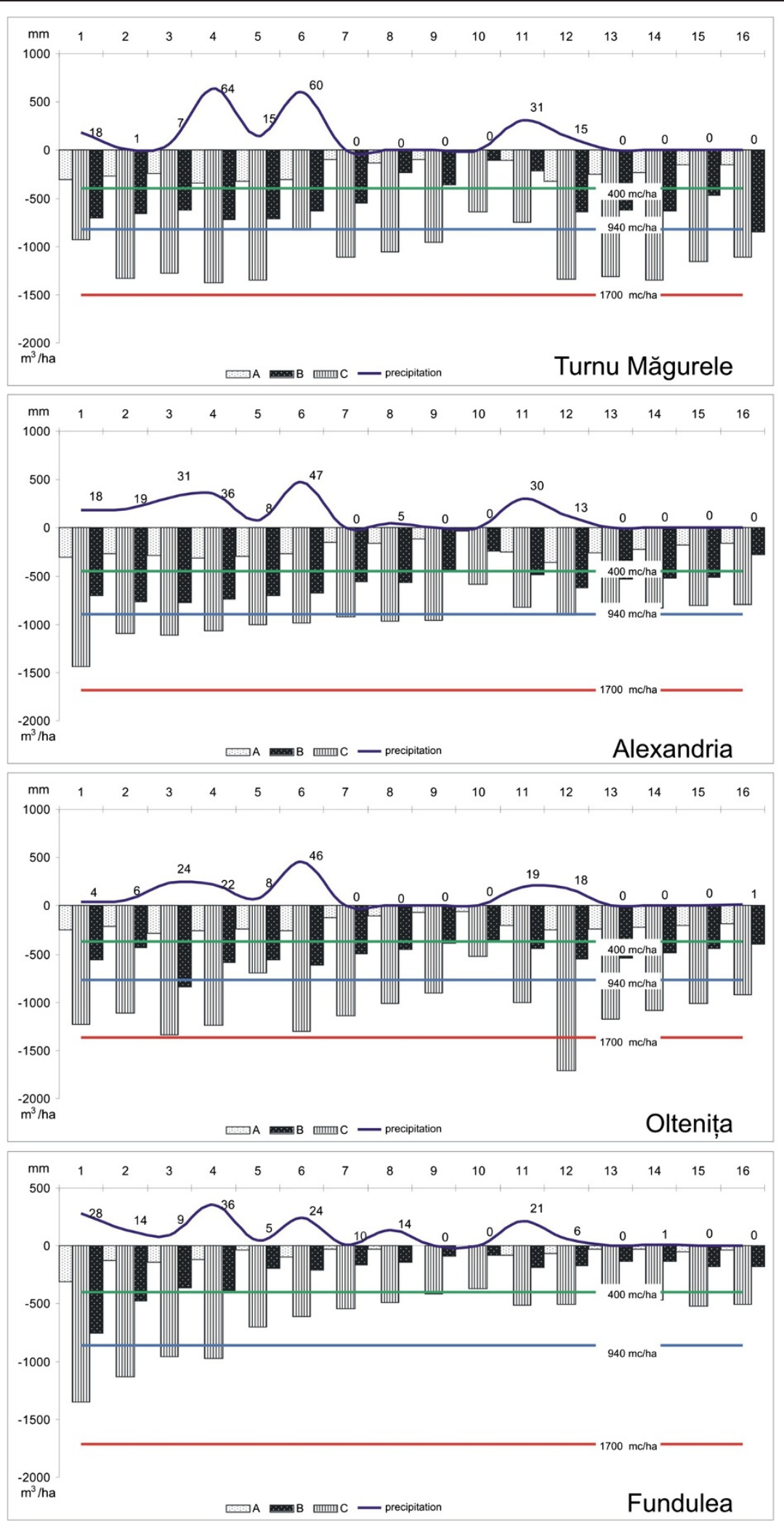

Figure 3 The average available moisture (AWC) and the soil moisture reserve for the agrometeorological station situated in the south of the plain (data source: National Meteorology Administration). 
With the agrometeorological stations situated in the north of the plain (Piteşti, Târgovişte, Ploieşti), located on the $30 \mathrm{~mm} /{ }^{\circ} \mathrm{C}$ isoline, according to the Romania aridity index map, deficits were observed in August (below $30 \mathrm{~mm}$ ), September $(0 \mathrm{~mm})$ and November $(5 \mathrm{~mm})$. Under these conditions, the soil moisture reserve fell drastically, to values much below the normal averages (Figure 2).

As regards the agrometeorological stations located on the $20 \mathrm{~mm} /{ }^{\circ} \mathrm{C}$ isoline, according to the same map (Turnu Măgurele, Alexandria, Fundulea and Oltenția and Buzău), the situation is similar in terms of precipitations, but with a slight extension between the decadal intervals towards the months of July and October (Figure 3).

\section{Conclusions}

The results of the study have emphasised the consequences of an agrometeorological phenomenon of risk, with negative effects mainly on summer-autumn agricultural crops, leading to a decrease of the agricultural production, but also with significant implications on the following agricultural year (2012-2013), due to inability to perform specific agro-technical works or, if they had been carried out, they had to be redone because seeding had been compromised.

Abbreviations
AWC: Available water capacity.

\section{Competing interests}

The authors declare that they have no competing interests.

\section{Authors' contributions}

OM participated in the conception, or acquisition of data, or analysis and interpretation of data, participated in the given final approval of the version to be published; GM participated in the conception of the study and performed the statistical analysis and graphics; MF participated in the analysis and interpretation of data, involved in drafting the manuscript or revising. All authors read and approved the final manuscript.

\section{Acknowledgements}

This article was put together with the help of information gathered from the Meteorological and hydrological stations at Târgovişte and from the Basarab I Emergency Inspectorate, Dâmbovița county.

Received: 20 November 2013 Accepted: 14 December 2014

Published online: 27 December 2014

\section{References}

1. Institute of Geography, Romanian Academy: Geografia României, vol V. Bucureşti: Ed. Academiei Române; 2006.

2. Cernescu N: Clasificarea solurilor cu exces de umiditate. In Cercetări de Pedologie. Bucureşti: Academiei RPR; 1961:223-250.

3. Berbecel O, Stancu M, Ciovică N, Jianu V, Apetroaiei Şt, Socor Elena, Rogodjan Iulia, Eftimescu Maria: Agro-meteorologie. Bucureşti: Ceres; 1970.

4. Berbecel O, Eftimescu M, Mihoc C, Socor E, Cusurzuz B: Cercetări privind resursele agro-climatice din RS România. Bultinul Informativ ASAS 1984, 13:33-43.

5. Apetroaiei Ş: Evaluarea şi prognoza bilanțului apei în sol. Bucureşti: Ceres; 1977.

6. Botzan M: Bilantul apei în solurile irigate. București: Academiei RSR; 1972.

7. Canarache A: Fizica solurilor agricole. Bucureşti: Ceres; 1990.

8. Canarache A: Indicatori climatici şi regimuri de umiditate şi temperatură a solului. Ştiința solului, Seria a III-a, SNRSS 2005, 1-2:XXXVIII. 66-78.
9. Păltineanu C, Chițu E, Seceleanu I, Tănăsescu N, Apostol G, Pufu MN, Păltineanu Rodica: Evapotranspirația de referință, consumul şi necesarul apei de irigație ale principalelor culturi agricole în solurile bazinului hidrografic Argeş - Vedea. Piteşti: Paralela; 1999:45.

10. Păltineanu C, Chițu E, Tănăsescu N, Apostol G, Pufu MN: Irrigation Water Requirements for Some Fruit Trees Specific to the Argeş - Vedea River Basin, Romania. In Proceedings of the Third International Symposium on Irrigation of Horticultural Crops. Lisboa, Portugal: Acta Horticulturae; 2000. 537, I, 113-119.

11. Păltineanu C: Comparison between Experimental and Estimated Crop Evapotranspiration in Romania. In International Agrophysics. Institute of Agrophysics, Polish Academy of Science: Lublin, Poland; 2005:19.

12. Păltineanu C, Mihăilescu IF, Dragotă C, Vasenciuc F, Prefac Z, Popescu M: Corelația dintre indicele de ariditate şi deficitul de apă climatic şi repartiția geografică a acestora în România. Analele Universității Spiru Haret Seria Geografie 2005, 8:23-28.

13. Păltineanu C, Mihăilescu IF, Seceleanu I, Dragotă C, Vasenciuc F: Using aridity indices to describe some climate and soil features in Eastern Europe: a Romanian case study. Theoretical and Applied Climatology 2007, 90(3-4):263-274

14. Păltineanu C, Mihăilescu IF, Prefac Z, Dragotă C, Vasenciuc F, Nicola C: Combining the standardized precipitation index and climatic water deficit in characterizing droughts: a case study in Romania. Theoretical and Applied Climatology 2009, 97(3-4):219-233.

15. Bogdan O, Niculescu E: Riscurile climatice din România. Bucureşti: SEGA International; 1999

16. Bogdan O, Marinică I: Hazarde meteo-climatice din zona temperată. Geneză şi vulnerabilitate cu aplicații în România. București: Universității "Lucian Blaga", Sibiu; 2007.

17. Croitoru A-E, Piticar A, Imbroane AM, Burada D-C: Spatiotemporal distribution of aridity indices based on temperature and precipitations in the extra-Carpathian regions of Romania. Theoretical and Applied Climatology 2013, 112(3-4):597-607.

18. Peptenatu D, Sirroev I, Pravalie R: Quantification of the aridity process in south-western Romania. Iran J Environ Health Sci Eng 2013 2013, 11:3.

19. Pravalie R, Sirdoev I, Peptenatu D: Changes in the forest ecosystems in areas impacted by aridization in south-western Romania. Iran J Environ Health Sci Eng 2014 2014, 12:2.

20. Murărescu O, Pehoiu G, Murătoreanu G, Turloiu R: Le déficit d'humidité dans le sol et son impact sur les activités agricoles dans la haute plaine située entre les vallées des rivières argeş et prahova (roumanie) - étude de cas (août-novembre 2011). 25ème Colloque de l'Association Internationale de Climatologie, Grenoble 2012, 2012:565-570.

21. National Meteorological Administration: Annual Report 2011, Bucharest; Romania.

\section{Submit your next manuscript to BioMed Central and take full advantage of:}

- Convenient online submission

- Thorough peer review

- No space constraints or color figure charges

- Immediate publication on acceptance

- Inclusion in PubMed, CAS, Scopus and Google Scholar

- Research which is freely available for redistribution 